\title{
Bilad al-Brazil: The Importance of West African Scholars in Brazilian Islamic Education and Practice in Historic and Contemporary Perspective
}

\author{
Ayodeji Ogunnaike
}

check for updates

Citation: Ogunnaike, Ayodeji. 2021. Bilad al-Brazil: The Importance of West African Scholars in Brazilian Islamic Education and Practice in Historic and Contemporary Perspective. Religions 12: 131. https://doi.org/10.3390/rel12020131

Academic Editor: Terry Lovat Received: 20 November 2020 Accepted: 10 February 2021 Published: 19 February 2021

Publisher's Note: MDPI stays neutral with regard to jurisdictional claims in published maps and institutional affiliations.

Copyright: (c) 2021 by the author. Licensee MDPI, Basel, Switzerland. This article is an open access article distributed under the terms and conditions of the Creative Commons Attribution (CC BY) license (https:// creativecommons.org/licenses/by/ $4.0 /)$.
Africana Studies Department, Bowdoin College, Brunswick, ME 04011, USA; aogunnai@bowdoin.edu

\begin{abstract}
While it is well established now that the middle passage did not entirely separate Africans who were forcibly brought to the Americas from their home cultures and traditions, these connections are often studied and understood in the form of survivals or ancestral memory. This paper argues that in major urban centers in Brazil until around the time of World War I, West Africans not only managed to recreate Islamic communities and intellectual traditions, but maintained important contacts with their homelands. In much the same way that scholars have argued that the Sahara constituted an avenue of exchange and connection between North Africa and Bilad al-Sudan, I argue here that the Atlantic Ocean was not an insurmountable barrier but provided opportunities for African Muslims to extend the traditions of Bilad al-Sudan into Brazil-albeit to a much lesser extent.
\end{abstract}

Keywords: Islam; Brazil; African diaspora; Black Atlantic; Bilad al-Sudan; education; Yoruba; Hausa; Salvador; Arabic

\section{Introduction}

Imagine traveling to Brazil in the nineteenth century and encountering a seventyyear-old man, fluent in at least three languages, literate in both Arabic and Portuguese who has won his freedom, undergone traditional Islamic education over three periods of his life in two different places in West Africa, and supports himself and his family entirely on his practice and teaching of Islam. While all of these characteristics together are remarkable and describe a Yoruba man named Abuncare, they are not nearly as unique as one might think. In fact, what is most remarkable about this man's case is that we are able to trace so much of his personal history. While it is well established now that the middle passage did not entirely separate Africans who were forcibly brought to the Americas from their home cultures and traditions, these connections are often studied and understood in the form of survivals or ancestral memory (Mintz and Price 1992). ${ }^{1}$ I will argue that in major urban centers in Brazil until around the time of World War I, West Africans not only managed to recreate Islamic communities and intellectual traditions, but maintained important contacts with their homelands. In much the same way that scholars have argued that the Sahara constituted an avenue of exchange and connection between North Africa and Bilad al-Sudan (Austen 2010; Lydon 2009; Scheele 2010), I argue here that the Atlantic Ocean was not an insurmountable barrier but provided opportunities for African Muslims to extend the traditions of Bilad al-Sudan into Brazil—albeit to a much lesser extent.

Following Paul Gilroy's Black Atlantic, more attention has been paid to the way the Atlantic Ocean served as a unified cultural, religious, and intellectual community for people of African descent in the modern era (Gilroy 1993). However, most such work has tended to focus on Christian communities, secular politics, Europhone intellectual

\footnotetext{
1 This theoretical perspective began with Herskovits with Mintz and Price calling for re-theorization in the 90s.
} 
traditions, and also the practice of traditional African religions. ${ }^{2}$ Furthermore, while some like Michael Gomez, Sylviane Diouf, and Edward Curtis have shed important light on the often overlooked lives of Muslims in the Americas during the colonial era (Gomez 2005; Diouf 1998; Curtis 2014), little has been produced on the ways some such communities established a type of Muslim Black Atlantic, forging important connections and continuities between West Africa and the Americas. While the scarcity of sources and the oppressive and repressive nature of slavery in the Americas makes such a task challenging at best, this is what I attempt to do here given that Muslim communities in Brazil offer unique possibilities for such a study. I pay particular attention to the determination and great deal of success that leaders in these communities found in recreating and maintaining specifically West African traditions of Islamic literacy and erudition.

This article consists of two main parts. In the first, I outline the geographic and ethnic origins of many of the Muslims brought to Brazil in the late eighteenth century to late nineteenth century. Fortunately, not only are such statistics and information available, but biographic information on specific — and often remarkable—individuals is also included along with the relevant historical events that led to their capture. Next, I explain how specific factors of Brazilian slavery (such as certain ethnic prejudices on the part of Brazilian society, the urban character of slavery, specific forms of slavery and manumission, and unique social organization) provided a unique opportunity not only to recreate Islamic communities, but to win converts and carry out a degree of education, as well. I will also go into detail to explain how, at their height, these communities closely mirrored and were likely linked to West African religious and political structures and how they ultimately fell into decline later in the twentieth century. Finally, I analyze the main features of the tradition of Islamic erudition in Brazil, including the production of amulets, establishment of schools, importation and recreation of written material and the tools necessary for their production, and participation in a limited Atlantic trade in Islamic religious goods.

In the second part of the paper, I focus on specific individuals who demonstrate both in historical and contemporary perspective how African Muslim scholars have been at the heart of a remarkably successful trans-national community in Brazil. The first main figure is Abuncare (known as Rufino in Brazil) who was active primarily in the nineteenth century in multiple urban centers in Brazil, and the second is Shaykh Abdul Hameed Abu Bakr Ahmad who currently runs the Mosque and Islamic Cultural Center in Salvador, Bahia. Both men are ethnically Yoruba, and managed to leverage trans-national religious networks in unique and creative ways. Through their history of a high level of Islamic education combined with important knowledge of and experience with West African ways of life, these scholars and religious leaders have been able to lead very successful careers in which they have exported West African Islamic traditions and helped them take root in Brazil.

\section{Origin of Brazilian Malês}

As a result of its heavy involvement in the slave trade (Brazil was the last country to officially abolish the slave trade in the Americas in 1851 and slavery in 1888), it has the largest population of black people in the world after Nigeria. However, Brazil also had a remarkably large number of Muslims who were forcibly brought to its shores beginning as early as the late eighteenth century. The first Muslims likely arrived in Brazil in the 1780s coming from the Central Sudan, as demonstrated by Paul Lovejoy's analysis of shipping records of the time (Lovejoy 1994). Many of these men-and almost all were men-were captured during the wars of Usman Dan Fodio, and were consequently mostly Hausa with a number of Fulani, Kanuri, and Nupe men as well. Surprised by how many of the African men he met in Bahia were literate, Francis de Castelnau (a prominent French naturalist

2 These works have also filled in a gap as Gilroy pays very little attention to religion in his work. For example, Matory (2005), Matory (1999), Mann and Bay (2001), Palmié (2013), and Capone (2011). Although well before The Black Atlantic, Ajayi had begun work with a similar scope and focus-Ajayi (1961). 
and consul in Bahia) provided several biographies of these men, most of whom came from city states such as Kano and Katsina that are located in present-day Northern Nigeria. These men were captured in the wars between Usman dan Fodio and the various Hausa states and later Kanem-Bornu (Castelnau 1951). According to the data analyzed by Lovejoy, between the period of 1805-1850, "it seems reasonable to conclude that at least 52.8 percent of the slaves exported from the Central Sudan to the Americas were Muslim," indicating that there was not only a sizeable Muslim population in Brazil at the time, but that many of them were captured, transported, and arrived together (Lovejoy 1994, p. 167).

Brazilian authorities were not ignorant of the identities of these newly arrived Muslims or their high level of literacy. After the most famous rebellion in 1835 in Bahia, the thenchief of police noted that "almost all of them know how to read and write using unknown characters that look like Arabic" and that "the former nation [Hausa] was the one that rebelled quite often in this Province, but has been substituted by the Nagôs."(Reis 1997). Nagô was the term used in Brazil and a few other places to refer rather roughly to the various sub-ethnic groups that shared mutually intelligible languages and cultural features and later became known under the pan-ethnic title, "Yoruba." ${ }^{3}$ In fact, as a result of internal wars between these various sub-groups, the Nagô/Yoruba began to arrive in much larger numbers beginning in the 1820s (Lovejoy 1994). As a result, Muslim communities, particularly in Bahia, which had the largest number of African-born slaves, were initially dominated by the Hausa and affiliated ethnic groups such as the Fulani and Kanuri (often referred to in European languages as Bornou or some variant at the time), but as the Yoruba began to arrive in increasing numbers they began to form a greater part of the community and even its leadership. This is further demonstrated by the fact that Muslims in Bahia and elsewhere came to be known as "Malês"— the Yoruba word for "Muslim."

Given the large numbers of Muslims who arrived in Brazil around and after the turn of the nineteenth century, it is no surprise that many of them "had certainly been members of an intelligentsia in Africa" (Reis 1997, p. 106), a fact demonstrated in the short biographies of Castelnau, another set of interviews with mostly Hausa slaves conducted by the former Portuguese minister D'Andrada in Brazil in 1819, and the court records left after the arrest of participants in the 1835 Male rebellion in Bahia. For example, D'Andrada recorded a man named Francisco as "full of integrity and intelligence" and a "Mohamedan priest" and schoolmaster who translated the Our Father into Hausa (de Drumond 1826, p. 205), and another named François who was "very intelligent and wise" who served as a "prêtre de la loi" (most likely a faqïh) in Kano before becoming enslaved (de Drumond 1826, p. 212). Dandará (most likely Dan Daura after the town in Northern Nigeria) was a free Hausa man who was "a teacher in his Land," and had been providing his coreligionists with Islamic education in a tobacco shop he owned (Reis 1997, p. 133). Another Nupe scholar named Sanim admitted during his testimony to being an alufá (Yoruba word for Muslim cleric/scholar) before coming to Brazil, but he denied teaching others once he arrived, possibly for fear of harsher punishment (Reis 1997, p. 133). Mohammad, a Hausa man, was a "marabout" from Katsina just like his father (Castelnau 1951, p. 39), and Ibrahim from "Bornu" was amongst the privileged few to have completed the Hajj along with his father before being captured. ${ }^{4}$ Perhaps the most interesting of such figures was the Fulani Mohammad-Abdullah. He was a marabout who also completed the Hajj, was literate in both Arabic and Portuguese, fluent in at least three (but likely more) languages, won his own freedom, and even tried "by all means" to convert Castelnau, whose money he rejected and of whom he apparently did not think highly, calling him "un chien de chrétien!"5 In

3 The term "Nagô" was used most frequently in Bahia specifically, but had currency in Francophone territories as well, taking on distinctive attributes unique to each location. The ethnonym "Yoruba" did not emerge until later; it covered a slightly different group of people and owed its existence to the experience of the Atlantic diaspora, including that in Brazil. See Reis and Mamigonian (2004), Awoniyi (1981), and Law (1997).

4 Ibrahim is recorded as from "Bernou" which is almost certainly Ngazargamu, the old capital of the Kanem-Bornu Empire. While the ethnonym "Kanuri" is more commonly used today, "Bernou" or "Bornu" was also used during colonial times. Ibid, p. 43.

5 Mohammad-Abdullah also provided a detailed description of his pilgrimage route through the Central Sudan to Mecca and was unsurprisingly a leader in his largely Hausa community. Ibid, pp. 46-48. 
fact, by the 1840s in Rio de Janeiro, the term "Mina" (the term used to refer to all Africans who had been sold on the coast between contemporary Ghana and Nigeria) "had taken on an additional meaning: that of proud, indomitable, and courageous Arabic-speaking Muslims, who were literate, intelligent, skilled, and energetic slaves who worked hard to buy their freedom." (Karasch 1987) Clearly, literacy in addition to Islam became closely linked to the identity of most slaves coming from the Bilad al-Sudan in the early nineteenth century, and their experience in West African wars made them more likely to take part in rebellions, as well.

Furthermore, the Malê population was quite significant even within the broader black and African population of Brazil at the time. Writing in the early 1900s, Nina Rodrigues estimated that at least a third of the old Africans were Muslim, indicating that they might have constituted a larger percentage before the rebellion in 1835 because many were deported afterward (Rodrigues 2010, p. 68). Diouf optimistically estimates that in the mid-to-late nineteenth century "there were probably thousands of highly literate, devout, practicing Muslims in [Rio]" suggesting that there were likely many more who could not read Arabic (Diouf 1998, p. 114). With such relatively large numbers, Muslim communities in Brazil's urban centers were not only sizeable but contained a decent number of scholars who could serve as leaders and teachers. In this light, it is perhaps not as much of a surprise that they were able to recreate the religious, social, and intellectual structures with which they were familiar back home, particularly given that practically all of them came from regions of West Africa that had been religiously and culturally linked for quite a long time. Still, most of these African-born Muslims lived under the yoke of slavery, but the particular conditions of urban Brazilian slavery offered unique opportunities for them to carry out this project.

\section{Nature of Brazilian Slavery}

A traveller entering Bahia [in the early nineteenth century] "might have supposed himself in Negro-land" (Kent 1970)

Several factors of the particular nature of Brazilian slavery that others have identified contributed to the many rebellions that took place primarily in Bahia in the early part of the nineteenth century, but they also surely contributed to creating a unique if still restrictive climate that allowed for the recreation of many aspects of religious life from West Africa. First among these factors were the Brazilians' perceptions of ethnic differences in African populations. In general, most of the Africans brought to Brazil came from the areas of West Africa already mentioned, Western Central Africa (contemporary Angola), and a much smaller number from the East coast of Africa (mostly present-day Mozambique). "Angolans" were believed by Brazilians to be more docile and better suited to agricultural work, and were consequently more often sent to large plantations outside of the city. The "Minas" from West Africa, on the other hand, were believed to be more intelligent and gifted with handiwork, and thus were often entrusted with crafts and vocations that were important but viewed as beneath their owners (Kent 1970, p. 339). This perception of Minas, which was undoubtedly linked to their comfort with urban life that had parallels in Hausa and Yoruba culture, resulted in their concentration in major cities and an identity as "'urban slaves' par excellence." (Gomez 2005, p. 95) Matory has noted how the concentration of such an ethnically similar population in Bahia was essential to the formation of Candomblé as a uniquely urban phenomenon (Matory 2000), and the same could certainly be argued for Muslim communities as well.

A major factor in this process was the ganho system. In this system slaves were free to practice their various trades almost unsupervised but would have to give a certain amount of income to their masters on a regular basis. If they were able to earn more than the established amount, they could keep the surplus and use it as they liked. As a result, these ganhadores were not even required to live in the same city or area as their masters and had much more control over their labor so long as they continued to supply a steady source of income to their masters. Ganhadores could often rent rooms on their own, manage their 
own time to a great extent, and had a good deal of freedom of movement and association within the city. This of course does not mean that it was always easy to meet the quotas or that the work was not grueling in many ways, but it did provide for much more relative freedom than plantation slavery. ${ }^{6}$ In fact, Kent argues that urban slaves "seemed hardly to be in a 'condition of bondage,' living and working literally on the streets of Bahia and moving freely day and night."

Many Africans, both ganhadores and freedmen, worked in groups called cantos particularly for tasks that would require multiple people like sedan carriers, porters, or stevedores at the port. These cantos were usually organized around ethnic lines, and later in the nineteenth century, $80 \%$ of the cantos were specifically Nagô (Reis and Mamigonian 2004, p. 86). This allowed African laborers to recreate social structures from their home communities, and because they were not working all of the time, they could engage in other group activities in between employment. Members of Muslim cantos, for example, "sewed Islamic clothes, studied Arabic, practiced writing, or read Islamic texts." (Reis and Mamigonian 2004, p. 86). A woman who lived across from the corner where one alufá's canto gathered recounted that they "for a long time had been making notes [in Arabic] ... and bringing together at that place others of their Nation ... to whom they taught to write with pointers dipped in ink they had in a bottle ... They even taught them prayers in their language." (Reis 1997, pp. 104-5). These cantos became such a powerful social and economic force, backed by ethnic bonds that they could often dictate or monopolize whole sectors of the economy. Bahian traders once made formal complaints when African slaves who grew manioc and other foodstuffs in their free time would only sell them to their compatriots, effectively freezing the Brazilians out of the market (Reis and Mamigonian 2004, p. 87)!

Those who saved enough money were legally allowed to buy their freedom from their masters, and again, ethnic solidarity played a major role in this process. By recreating rotating credit associations popular in West Africa, Mina slaves were able to join together around cantos and religious groups to pool resources to buy the freedom of each member in turn until they were all free (Kent 1970, p. 340). Sanim, one of the Nupe leaders of the 1835 rebellion, organized one of these groups (called esusu in Yoruba) not only to buy freedom for members but also to buy clothing for them (Goody 1986). This meant that ethnic and religious solidarity allowed a faster route toward manumission and consequently an even greater degree of freedom - economic and otherwise - for those involved. In addition, a large number of these African laborers engaged in multiple forms of work to supplement their income. An enslaved Hausa fisherman made the rough equivalent of the quota often owed to a master in 1835 through leveraging his knowledge of Islamic sciences and selling protective prayers written in Arabic on pieces of paper in his spare time (Reis 1997). Those who had already bought their freedom often required less money from their labor and could afford more downtime. Muslims often used this time to teach others, further their own education, or make a profit by offering their services to other Muslims and non-Muslims alike. ${ }^{8}$

Because of all of these facets of Brazilian slavery, a considerable number of Africans were able to buy their own freedom while others were granted freedom by masters in some cases, and "the houses of African freedmen also provided space for Malê worship, meals, celebrations, and of course conspiracies." (Reis 1997, p. 104). Freedmen and slaves often lived together, with ethnicity and religion often forming the basis on which Africans chose their living arrangements (Reis 1997, pp. 179-80). Indeed, many Muslims chose to live

6 For more on the ganho system and analysis of the ways it was used to support resistance, see Reis (2019) and Reis (1997).

7 Although by this Kent means that the conditions of freedmen and ganhadores were remarkably similar in appearance, not necessarily that this form of slavery was entirely benign. Moreover, the lives of freedmen were of course very difficult as well given the oppressive racial structure of colonial Brazil. "African Revolt," p. 342.

8 It is interesting to note the similarities between the ganho system and the Murgu tradition in the Sokoto Caliphate around the same time, most notably the ability of slaves to acquire money, buy their own freedom, establish their own houses, and generally exercise a certain degree of independence with less direct oversight. This would surely have made the nature of Brazilian urban slavery more readily intelligible to Hausa and other ethnic groups whose traditions of "slavery" differed greatly from European chattel slavery (Lovejoy 1993). 
together for these reasons, indicating that Hausa and Yoruba Muslims could spend their entire days working, eating, sleeping, and even praying and studying with coreligionists.

Urban Muslims formed their own internal communities that closely resembled those they left behind in West Africa, as well. The leader of these communities was called the Limano, and he oversaw a number of other clerics called marabus or alufás within his city. Nina Rodrigues cites a Mala Abukar as the Limano during the Malê rebellion in 1835, ${ }^{9}$ and it appears that because of the high concentration of Muslim scholars in Bahia, it was the center of this new Muslim diaspora. Ricard and Gomez record Bahia as remaining the center or seat of Islamic authority as the imam there was responsible for appointing the imams in other areas such as Rio de Janeiro, Pernambuco, and Ceará (Ricard 1948 and Gomez 2005, p. 123). The imam in Bahia also set the calendar for the entire community, establishing when Ramadan and other months of the Islamic calendar would begin and end based on moon sightings (Brazil 1909), and there were several other titles or positions taken directly from Yoruba and Hausa society such as the alikaly, who Gomez believes indicates a maintenance of Islamic law (Étienne 1909; Ricard 1948; and Gomez 2005, p. 123). This particular configuration of authority is quite reminiscent of Hausa, Yoruba, or even medieval Songhay society in which certain city states such as Sokoto or Gao and their religious leaders possessed the authority to appoint others in subservient or affiliated city states who would roughly recreate the same model within their own jurisdiction. ${ }^{10}$

Following the rebellion of 1835, Bahian authorities sought to deport free African Arabophones. While they were not completely successful in this endeavor, some were sent back to Africa (Goody 1986, p. 326), and many more were sold to other parts of the country. While many were sold to other urban centers-most notably Rio-many freedmen chose to escape the subsequent repressive situation of heightened state oppression and surveillance by voluntarily moving to other cities as well. ${ }^{11}$ Some even bought passage back to West Africa, but as more and more gained their freedom, the rate of repatriation declined sharply around 1870 as some preferred to stay within their community (Gomez 2005, p. 121). The number of Muslim repatriates in major trading centers on the West African coast was so high that in 1859 the British Consul decided that it needed to issue passports in both English and Arabic to their large number in order to help them return to their homes in Hausa, Nupe, and Yorubaland (Law 2004, p. 357). Some also remained on the coast and were either the leaders or founding members of Muslim communities in practically all the major trading ports in the area including Agoué, Ouidah, Porto Novo, Lagos, and Badagry. ${ }^{12}$ As a result of this forced and voluntary dispersal, the Muslim population of Bahia was greatly reduced, but it never lost its place as the seat of Muslim authority in the area and could be considered to be the nexus of a Muslim and trans-Atlantic Afro-Brazilian network that extended across major urban and trading centers on the Brazilian and West African coastlines.

In a fascinating turn of events, an Arab cleric named 'Abd al-Raḥmān al-Baghdādī was blown off course while carrying out an Ottoman mission in 1865, landed in Rio de Janeiro, and provided a unique account of the state of some of the Muslim communities in Brazil in a travelogue entitled Masaliyat al-Gharīb or "The Amusement of the Foreigner." When he disembarked, he was surprised when a black man dressed in Western clothes greeted him by saying "as-salāmu 'alaykum", but he later realized that the man and his community of about 5000 other Muslims were from Bilad al-Sudan and most had gained their freedom by that point (al-Baghdādī 2001, pp. 7-8). Al-Baghdādī's account differs a bit from most other sources on the level of erudition within the community. He recorded that

9 Although the identity of this man could not be confirmed through the court records. Reis believes it could have been another named Ahuna (Rodrigues 2010, pp. 68-69 and Reis 1997, p. 130).

10 Although this type of authority could always be contested as it was in Songhay (Hunwick 1996 and Gomez 1990).

11 Some even banded together in Rio as they had done in Bahia and bought their freedom after having been resold in Rio. (Reis and Mamigonian 2004, p. 100; da Costa e Silva 2001; Gomez 2005, pp. 116-18).

12 For example, the Da Gloria family produced three generations of imams for the Nagô mosque of Agoué. See (Castillo 2016; Law 2004, pp. 359-60; Lovejoy 1994, p. 168). 
"their hearts are sick of ignorance. Because they left their country when they were very small, none of them have learned the religion of the Chosen Prophet," (al-Baghdādi 2001, p. 8). and only some had memorized the first juz' of the Qur'an (al-Baghdādi 2001, p. 13).

Al-Baghdādī left a document with the Rio community with instruction on various rites as well as hadìth (al-Baghdādī 2001, p. 14), and he also may have started the international trade in Qur'ans in Rio when he asked a bookseller there to import more copies from France (al-Baghdādī 2001, p. 16). He stayed for a year teaching in Bahia because a man had come to ask him to do so, and while he noted that the Muslim population in Bahia was still greater than that of Rio, he was equally unimpressed with their practice of Islam (al-Baghdādī 2001, pp. 28-29). Apart from his disapproval of women not wearing the veil or fasting during Ramadan, he also did not approve of the way some men drank alcohol, mandatory baptism in the Catholic Church, and that the leaders were "totally occupied with geomancy and natural magic." (al-Baghdādī 2001, pp. 16-19). He also visited Pernambuco briefly, although he only remarks on the names of two leaders and the community's inclination to "magic geomancy, and prophecy."13 While al-Baghdādī's insights are certainly useful, other evidence paints a more positive picture of Brazilian Muslim communities, and his critiques seem to echo those heard in past and contemporary times from Arabs that are racially inflected. However, his voyage does demonstrate Reis, Gomes, and de Carvalho's observation that this community was "a truly national network of coreligionists and not isolated groups." (Reis et al. 2010, pp. 420-21). ${ }^{14}$

Still, Al-Baghdādī was likely documenting the general decline of the level of Arabic literacy and Islamic knowledge within the community. In 1909, Ignace Étienne claimed that leaders in Bahia could no longer read the Qur'an but had to rely on a Portuguese translation. However, a bookstore still managed to sell a few books in Arabic, although it is not known whether or not those who bought them could fully read them (Brazil 1909, p. 75). Da Costa e Silva records that the previously profitable Rio trade in Qur'ans had died out by the early twentieth century, indicating perhaps not only a decrease in literacy but also in the size of the community. Étienne further provides a remarkably conservative number of no more than a few hundred Muslims in all of Brazil at the time (Brazil 1909, p. 74). Indeed, Nina Rodrigues estimated that they would disappear shortly after the turn of the century (Rodrigues 2010, p. 67), but Monteiro made a case for the community surviving until as late as the 1970s and 1980s although the full extent of their practice of Islam is more open-ended (Monteiro 1987, pp. 13-19, 63-74; Gomez 2005, p. 126). Verger and Monteil argue that the last Malê in Bahia, a Yoruba man named Jibril, died there in 1959 (Monteil 1967). Taken together, it is clear that as a result of the wars in Hausaland at the end of the eighteenth century and in Yorubaland at the beginning of the nineteenth century, a large number of Muslims were forcibly brought to Brazil, particularly Bahia, and the community reached its peak around the mid-nineteenth century at which point some began returning to West Africa. As those who came from Africa with a high degree of Islamic education got older and began to die, the level of Arabic literacy likely declined with their numbers, but as we will see, the successful recreation of educational institutions did ensure that subsequent generations were given access to this type of education as well.

\section{Scholarly Activity}

Il revient sans cesse à la foi de Mahomet... qui, suivant lui, est la seule chose de ce monde qui vaille la peine qu'on s'en occupe. (Castelnau 1951, pp. 47-48)

The above quotation comes from Castelnau's biography of Mohammad-Abdullah, the Fulani man who attempted to convert him, and demonstrates the high level of dedication many of the Brazilian Malês demonstrated toward their religion. In fact a non-Muslim

13 In addition to the general context of the distaste of travelers such as al-Baghdādī for West African esoteric and talismanic traditions, it is worth noting that the tradition likely would have acquired heightened significance given the oppressive nature of colonial Brazilian society and the unique options it provided for protection and prosperity (al-Baghdādī 2001, p. 32).

14 An English translation of the book has recently been published as well (Reis et al. 2020). 
freedman criticized the Malês by saying, "they all want to be priests"(Reis 1997, p. 110), indicating that they were all inclined towards further religious study: a fact which is unsurprising given many of their backgrounds and also the conditions in nineteenth century Brazil. Many of the Malês who were brought to Brazil had already progressed quite far in their Islamic education by the time they were taken captive, and it seems unlikely that they would abandon these spiritual and intellectual pursuits if given the time. Islamic education and Arabic literacy were central aspects of Muslim life in Brazil, but they have not received the full attention they deserve in part because the writings produced by African Arabophones has been largely interpreted through the lens of rebellion and resistance both from contemporary government agents and subsequent scholarship. Despite some early claims to the contrary, many converts were made in Brazil, and Arabic literacy was likely a major draw for them. There is also clear evidence that some type of schools were established, and teaching was not always carried out in secret either. There seems to be concrete proof of novices learning the rudiments of Arabic literacy in such schools alongside the work of those who had a high degree of education as well. Aspects of West African intellectual traditions were recreated both in the form of material culture-such as writing utensils—and manuscripts and books. Finally, similar forms of examinations and certifications were recreated in Brazil, and there is a certain amount of evidence for continued engagement with scholarly works that were circulating in West Africa at the time as well.

Although the Malê community did slowly decline in the second half of the nineteenth century, during the first half, it is clear that the contemporary state of affairs in West Africa continued in Brazil as well; namely, that more and more people came to embrace Islam. Nina Rodrigues claimed that Muslims did not proselytize, but I join Reis in parting ways with him and Roger Bastide who argued that the Malês were quite passive in this respect (Reis 1997, p. 98). Some of this "missionary work" was indeed rather discreet (da Costa e Silva 2001), and while the level of commitment may have varied amongst some converts, conversion certainly occurred. Law records many Muslims who returned to West Africa having been converted in Brazil and choosing to maintain their practice of Islam when repatriated, perhaps the most famous being José Paraïso who participated in the Male rebellion and ultimately became one of the most important political figures in Porto Novo in present-day Bénin (Law 2004, pp. 359-60). While exact figures would be impossible to determine and are beside the point here, what is significant is that the Muslim communities in Brazil were committed to reestablishing their traditions in their new and hostile home and were quite successful given the circumstances.

As mentioned before, there was no shortage of qualified religious scholars and figures who could draw in and educate potential converts. Their high level of education produced a strong sense of pride and confidence, as the case of Mohammad-Abdullah demonstrates above, and he was by no means an exception. Castelnau noted quickly upon his arrival in Bahia that many of the Muslim slaves could read and write Arabic and "lybique," (Castelnau 1951, p. 5) and George Gardner, an English botanist, remarked that many of them could both read and write Arabic and were "tolerable Arabic scholars." (Gardner 1849, pp. 15, 59). Similarly, Thomas Ewbank, another English traveler, praised the Minas' intelligence and even suggested that "some write Arabic fluently, and are vastly superior to most of their masters." (Ewbank 1856, p. 439). Writing much later in the twentieth century, the famous Brazilian social theorist Gilberto Freyre took this line of thinking even further:

“[Brazilian Muslims] were culturally superior ... to the great majority of the white colonists-Portuguese and the sons of Portuguese, with almost no education, some of them illiterate, most of them semi-literate ... Almost none of them were 
able to sign their names, and when they did so, it was in a broken script, like that of a child learning to write." 15

The widespread nature of a high degree of Islamic education made West African scholars stand out even to those who operated within a framework of assumed racial superiority and strongly challenged any claims against their biological inferiority to white masters.

Unfortunately, most of what we know about the output of these figures is limited to amulets and the talismanic tradition, which was apparently quite lucrative in colonial Brazil. Because the study of African "fetichism" was en vogue at the time, it is unsurprising that scholars such as Bastide and Étienne Brazil were fascinated by it (Bastide 1978, p. 150 and Ricard 1948, pp. 78, 95). While Reis finds that amulet making was likely not lucrative enough to support a slave or freeman in Bahia (Reis 1997, p. 102), it does appear to have generated enough for the Hausa fisherman Antônio to pay his master if he had one (Reis 1997, p. 171). This tradition was clearly carried over from West Africa and employed in many of the same ways. People of all religious and racial backgrounds patronized those who knew how to make talismans, and they were particularly prevalent in times of war and rebellion. Many fragments of paper and other talismans were seized following each rebellion in which Malês took part, and a decent number of them have been analyzed to a certain degree (Monteil 1967; Reichert 1967; Reis 1997, pp. 99-102; Rodrigues 2010, pp. 70-74; Dobronravin 2009, pp. 217-236). Monteil identified the reproduction of several common parts of the Qur'an in some of these talismans including ayat al-Kursī and alMu'awwidhatayn used to protect members of the 1835 rebellion (Monteil 1967, pp. 93-94). Even the tradition of using different colored ink for different purposes, such as writing the name of the client in red ink rather than black, were preserved, as was the common practice of drinking the water that washed off verses written on wooden boards. ${ }^{16}$ As in West Africa, some of these clerics were not involved in the violence themselves, but rather made or sold charms for those who needed them. Still, the fear of Arabic literacy was so great, that anyone found to have made or be in possession of such material was subject to arrest and prosecution (Reis and Mamigonian 2004, p. 98).

It was this fear of highly educated, proud, organized, and resistant Muslims that caused Brazilian authorities and many early scholars to interpret all written material in Arabic as either a magic charm to be used in warfare or politically "subversive."17 Immediately following the 1835 rebellion, the Bahian chief of police instructed justices of the peace to have their agents "enter every house and loge belonging to black Africans and search them rigorously for men, arms, and 'written papers,'" as these were used as proof of guilt even though the courts were completely unable to translate such papers on their own (Reis 1997, p. 192). Kent posited that the Brazilian authorities interpreted Arabophone Muslims as potential sorcerers or "mandingueiros" and a danger to public order because of the history of the Almoravids and Almohads in Iberia (Kent 1970, p. 341), but the cognitive dissonance of African Muslims' intellectual, political, and military ability as a legitimate rival to their own surely played a massive part. Despite the fact that such papers were often used as proof of insurrection, Reichert's analysis of twenty-five Arabic documents taken during the 1835 rebellion demonstrated that "there was nothing revolutionary in these papers, nothing 'subversive,'" as they were prayers and Qur'anic verses without any discussion of politics or conspiracy (Reichert 1967, p. 101). ${ }^{18}$

15 These observations from travelers and Freyre are interesting to compare to those noted by others in West Africa shortly before and around the same time period. Particularly that many West Africans_and the Fulani in particular-had a high rate of Arabic literacy, indeed often much higher than the literacy rate in Europe at the time (Kane 2016; Freyre 1986, p. 298).

16 See Goody (1986, p. 328), for more examples and details of these talismans and their similarities with those in West Africa (Rodrigues 2010, p. 74).

17 This provides a fascinating counterexample to the French stereotype of the more pacific "Islam noir" that dominated their colonial policy in West Africa.

18 Dobronravin similarly analyzes "prayer books" which also had a heavily devotional bent, noting as well that they could also be used for protection (Dobronravin 2009, pp. 223-34). 
This, however, did not stop even scholars from taking such an approach as Étienne identified a common West African divination square as a "rebel order of battle" (Étienne 1909, p. 406). Although he tried to take a positive approach to the literary activity of African Muslims in his Slaves and Masters, Gilberto Freyre interpreted such practices within the framework of witchcraft, charms, and insurrection as well. As IsfahaniHammond puts it, "the ink loses its purpose as a marker of scholarly erudition to become a potion used for 'black magic.' This cliché of the dreadful African supernatural registers panic about ... the potentially subversive role of black writing ... Freyre produces black agency as an irrational force that must be contained" (Isfahani-Hammond 2014, pp. 170-71). The sad fact of the matter is that because of this irrational fear of anything written in Arabic script by Africans in Brazil, most of the documents available are talismans taken from those who participated in slave rebellions, and other written material related to African Arabophone traditions of erudition are not readily available. However, given the number of places of learning that existed and the limited evidence available, these were produced as well.

The creation and operation of Qur'anic schools specifically “[w]as a purely African phenomenon; it was the actual transposition to America of African didactic methods and supplies" (Diouf 1998, p. 121). These schools were often set up in the houses of free Muslims who had more control over their living quarters or were rented with the pooled resources of a group, and both education and prayer took place in these settings (Bastide 1978, p. 146 and Reis 1997, p. 105). For example, Licutan, one of the leaders of the 1835 rebellion, was the head of a group that rented a back room in downtown Salvador that was used for all of these purposes (Reis 1997, p. 179) and I have already mentioned how Dandará opened his tobacco shop for education and prayers as well. However, these mosques/Qur'anic schools were not always established in secret. An English merchant allowed some of his slaves to learn Arabic from more learned Muslims, but later changed his mind and burnt all of the manuscripts they had accumulated (Reis 1997, p. 109). Another actually allowed two slaves to construct a hut where they could practice Islam and receive instruction openly, but forced them to demolish it following pressure from a justice of the peace (Reis 1997, pp. 105, 109). After 1835 in Bahia, Africans were no longer allowed to rent property unless a justice of the peace approved it (Reis 1997, p. 225), but in Rio, al-Baghdādī met with its Muslim community in a large house that was rented specifically for religious activity (al-Baghdādī 2001, p. 10).

It is clear that many levels of education were present in these Qur'anic schools from the fragmentary evidence that is available. Following the rebellion, a slave named Carlos admitted that he did not then know how to read or write Arabic but was being instructed by several figures, including one of the leading alufá who also led religious services. ${ }^{19}$ Later analysis of some of the documents recovered during the same period revealed some that demonstrate "the devoted zeal of the student repeating the sacred text dozens of times" either as practice or perhaps a set number of times to complete a formula (Reichert 1967, p. 101). Another fragment that Nina Rodrigues had analyzed was identified as likely produced by more novice students because of the number of incorrect words, misspellings, etc. (Rodrigues 2010, p. 72). At the same time, it is already known that individuals like Dandará and Sanim had been teachers before coming to Brazil and continued to do so after their captivity and were likely already highly literate (Reis 1997, p. 133). Some of the documents available "reveal the hand of a well-educated, cultured author (Reichert 1967, p. 101), ${ }^{20}$ and these were surely written by men such as these or Mohammad-Abdullah.

19 He very likely also could have been lying about how much education he had received out of self-interest as it was abundantly clear that the colonial authorities viewed all well-educated Muslims with suspicion (Reis 1997, p. 134).

20 Some of the manuscripts analyzed by Dobronravin contained both a high register of Arabic literacy and more elementary Arabic writing, phoneticized in African languages (Dobronravin 2009, pp. 223-32). 
Diouf raises an important point that many marabouts intentionally obfuscate their writings by substituting letters, leaving out some words or letters or generally writing in an "unclear manner" to preserve their secrets or prevent their formulas from being used by any but those they authorize. ${ }^{21}$ It is interesting to note that the fragments Rodrigues' interlocutor identified as "deformed" Arabic as a result of missing letters or truncated words, might constitute an example of this type of intentional obfuscation rather than a lack of education..$^{22}$ Apparently some of the "spurious Arabic" noted by those who tried to translate some of these documents was mixed in with African languages as well, indicating that perhaps not all of the documents were written in Arabic and the African Arabophones continued the tradition of Ajami. Rodrigues' correspondent recognized that what he identified as a talisman was at least partly not written in Arabic, but "an African dialect written in Arabic characters" (Rodrigues 2010, p. 72). Monteil, for his part, recognized that the last of the twenty-five documents he was able to analyze was "without doubt not in Arabic (maybe in Yoruba or in Hausa?)" (Monteil 1967, p. 98), and Dobronravin provides an impressive in-depth analysis of several folios containing mostly Hausa Ajami to the extent that he could draw out structural themes common across the genre (Dobronravin 2009, pp. 223-34 and Dobronravin 2014, pp. 159-72). In short, it was not just writing in the Arabic language that was maintained and recreated, particular approaches to the written word in amulets and formulas, as well as Ajami, were also a part of the impressive Arabic literary tradition in Brazil. This need not be too surprising either given that all of these aspects of the written word could carry added significance in a slave society with its associated dangers and vicissitudes.

The material and practical aspects of writing were also replicated to an impressive degree. First and foremost, despite the fact that paper was very expensive in Brazil as it was in West Africa, the output of literate African Muslims was simply astounding (Reis 1997, p. 106). The same police raid that produced the texts with allegedly "spurious Arabic" revealed an "infinity of papers written with different inks and ... some books also in manuscript [emphasis mine]" (Reis and Mamigonian 2004, p. 100). When an English merchant turned in Islamic materials owned by his slaves to an inspector, he collected them into a crate containing multiple Arabic texts, books, writing tablets, and rosaries (Reis 1997, p. 195). The donor of a prayer book to the Brazilian Historical and Geographical Institute commented that "Many similar, and bigger, books were found, as well as separate papers that we attribute to be their proclamations" (Dobronravin 2009, p. 232). While not found in Brazil, some paper used by a slave in Georgia had in fact been produced in Italy for the Islamic West African market and had found its way to him through this route and then across the Atlantic Ocean (Diouf 1998, p. 115-16). Whether brought directly from Europe, produced more locally, or again drawing from connections to West Africa, African Muslims in Brazil heavily invested the money they could manage to save in paper and a large number of books, and they even managed to reproduce their methods of writing on such paper.

The most common black ink was produced locally by burning rice, just as was done in West Africa. The wooden boards called wala in Hausa and Yoruba were widely used for teaching lessons, and this practice was continued until at least 1906 in Rio de Janeiro (Gomez 2005, p. 122). Many were found during the police raids following rebellions (Gomez 2005, p. 325 and Gomez 2005, p. 107), and frequent mention is made to the practice of drinking the water used to wash off the boards after they had been used to write ayat of the Qur'an (Brazil 1909, pp. 85-86; Étienne 1909, p. 104 and Rodrigues 2010, p. 74). Those who were masters as well as novices all wrote in what could easily be identified as the Maghribi script that was the norm in West Africa (Reichert 1967, p. 101;

21 This is still commonplace in West Africa today, and it seems reasonable that Brazilian alufá would bring this tradition with them, particularly within the context of police surveillance and oppression (Diouf 1998, pp. 119-20).

22 At the same time, there are important orthographic differences between the Maghribi script and "newer" script that was dominant elsewhere and likely where the script was analyzed. If an alternative held up as the standard against which the Malê's documents were compared, some of the "deformations" may have simply been differences in the way certain letters were shaped and dotted (Rodrigues 2010, p. 72; Blair 2008, p. 60). 
Monteil 1967, p. 90), ${ }^{23}$ and it could potentially even have been the specifically West African variant sometimes known as "Sudani" as well (Blair 2008, pp. 60-61).

Although it was not the primary use of the written word for them, the Malês also leveraged their Arabic literacy to correspond with each other within and across different urban centers. Some papers contained instructions about when and where to meet in Bahia leading up to the rebellion in 1835, but they existed in much smaller numbers than the amulets, prayers, and other written religious material (Goody 1986, p. 325). In 1849, the chief of police in Rio de Janeiro observed that the Malês there not only communicated with each other in "ciphered writings," but also were in communication with other Minas in Bahia, São Paulo, and Minas Gerais (Reis and Mamigonian 2004, p. 100). While he simply stated that these correspondents were "of the same nation," they were almost definitely Muslim as well because no others would likely have been able to read letters written in either Arabic or Ajami. Karasach even rightly suggests that such correspondence likely often had to do with trade and exchange of important goods, some of which likely came from important West African ports (Karasch 1987, p. 90). Again, the available evidence points to an ongoing community of mostly Yoruba and Hausa Muslims who were literate in Arabic and recreated the type of urban networks with which they were familiar at home and used their Islamic education to do so.

It has been well documented that a prosperous trade emerged between West Africa and Bahia, particularly after large numbers of Africans and some of their descendants returned to coastal cities in West Africa, but most attention has been directed toward general cultural items and those related to the practice of traditional Yoruba religion (Matory 2005; Turner 1942; Lindsay 1994; Law 2004; da Costa e Silva 2001, p. 88). Many of the wealthiest families in this trans-Atlantic world made their fortunes specifically through the lucrative trade that held this cultural zone together, and there is no reason to assume that Islamic items might not have formed a part of this larger West African trade. The trans-Atalntic trade in specifically Islamic goods has drawn little attention because it was likely carried out very discreetly and potentially unofficially so as not to attract too much attention to all parties involved and compromise participation in other forms of trade. In addition, most Africans were barred from reentry to Brazil following the Malê Rebellion, but many did carry out commercial voyages to Brazil albeit in secret. ${ }^{24}$ Diouf has documented how religious items from West Africa found their way to Muslim slaves in areas in which no such common and lively trade existed (Diouf 1998, pp. 115-18), and the trade must have been even more lucrative in areas like Salvador and Rio that had large Muslim populations. Freyre records Malês importing from West Africa blue ink used in writing formulas to be consumed on blackboards as well as the tecebas (the Yoruba tessuba or Arabic tasbih h) rosaries from there as well. ${ }^{25}$ It is known that Fulani and Manding slaves who had bought their freedom in Brazil returned to West Africa and carried out trade between West African ports and Brazil, taking part in the general trade in items such as kola nuts and African fabric, but also rosaries, ink, and likely wooden tablets and Qur'ans, as well (Diouf 1998, p. 115).

In fact, it was the trade in Qur'ans that seems to have been particularly lucrative. Comte de Gobineau, the French minister in Brazil, recorded in 1869 that the French bookstore Fauchon and Dupont in Rio sold about 100 copies of the Qur'an every year and it became their best seller (da Costa e Silva 2001, p. 88)! Malês would go to extreme lengths to buy them, sometimes going into debt for a whole year in order to finance their acquisition (Raeders 1934; Diouf 1998, pp. 114-15). As de Gobineau observed that many slaves bought these Qur'ans it is clear that they prioritized buying the Holy Book even more than their own freedom, and it is not difficult to imagine them leveraging their rotating credit asso-

23 Étienne does not name the Maghribi script specifically but notes its orthography (Étienne 1909, p. 100).

24 In addition, it appears that many of these African merchants, Muslim and non-Muslims, were involved in the slave trade to varying degrees, and a treaty with the British in 1831 made the slave trade officially illegal (Castillo 2016, pp. 31-32).

25 This trade in prayer beads apparently had just stopped in the early twentieth century, and it would have been interesting to know if items imported from West Africa took on added spiritual importance in the same way that they did for those involved in traditional Yoruba religion (Freyre 1986, p. 317). 
ciations to be able to buy one. Fauchon and Dupont were also able to make a substantial profit selling French Arabic grammar books which were bought by those who wanted to learn Arabic, particularly the young who were either unable to study Arabic in West Africa or were born in Brazil (da Costa e Silva 2001, p. 84). Although it is often assumed that the bookstore was serving the Rio Malês, given the strong network that connected them with Muslims in other major urban centers, it is possible that these Qur'ans found their way to other cities as well. Gomez makes the fascinating connection that it could have been al-Baghdādī who began this lucrative trade in 1865 by asking the owners of a bookshop in Rio to order more Qur'ans after buying their only copy (Gomez 2005, p. 121).

Qur'ans did not come only from Europe, however, as the last Malê reported in Salvador owned a Qur'an that was printed in and imported from Nigeria (Monteil 1967, p. 88). Karasach also believes that some of the fragments of the Qur'an found in raids in Rio likely were brought first to Bahia from West Africa before subsequently being transported to Rio (Karasch 1987, p. 90). It is also quite possible that some Qur'ans—or at least parts of the Qur'an-were simply transcribed from memory. Some slaves in other parts of the Americas were able to complete this task under extreme circumstances, ${ }^{26}$ and many of the Brazilian Malês had won their freedom, had a decent amount of free time on their hands, clearly had access to most of the materials they would need to carry out such a task, and had access to large communities that would surely support them in such work. If they were willing to go into debt for a year to buy imported Qur'ans from Europe and could pool resources together to buy their own freedom, it seems reasonable that they could help to support a scholar who might attempt to transcribe the Qur'an. Moreover, it is reasonable to assume that those who had taught in West Africa and were captured well into adulthood like Mohammed-Abdullah, Licutan, or Dandará would have memorized the Qur'an long before then as this was often completed by the teenage years in most scholarly families. Of all places in the Americas, Brazil probably had the largest numbers of "walking Qur'ans" - to borrow Rudolph Ware's phrase-in the eighteenth and early nineteenth centuries with some of the most favorable conditions for transcription (Ware 2014).

However, scholarly activity in Bilad al-Brazil went beyond merely teaching Arabic literacy, amulet making, and transcribing the Qur'an. Writing a series of articles on the different religious traditions present in Rio de Janeiro in 1906, João do Rio documented how the Malê would ordain new alufá. Young people who sought to become alufá in their own right had to study quite hard and were subjected to an examination by other alufá on their knowledge of the Qur'an if not other areas as well. Once they had successfully completed their studies, they would be paraded around the streets on horseback to great fanfare (do Rio 1906 in Karasch 1987, p. 285). Diouf notes how do Rio's description is practically identical to Blyden's description of the same ceremony just decades later in West Africa (Diouf 1998, p. 121). This observation is significant because it indicates that the community in Brazil was capable of both producing and examining new scholars, which strongly challenges the picture painted by al-Baghdādī of a poorly educated community and the claims of those like Rodrigues who believed that it was almost exclusively those born in Africa who were committed to Islam in Brazil. Despite the community shrinking in size after the turn of the twentieth century it was still large and devoted enough to train, test, and approve new scholars and do so in a way that was consistent across diaspora and homeland.

It can also be established that Brazilian Muslim communities also engaged with other sources beyond the Qur'an in their study and practice of Islam. A document translated for a justice of the peace in Bahia in 1835 was identified as a calendar "which the Malês use to keep track of their fasts and to know when to slaughter their rams," indicating that one of the leaders had likely recreated it from memory or perhaps acquired material from West Africa to which he referred (Reis 1997, p. 108). Reichert observed that most

26 For example, a slave named Benjamin Larten in Jamaica accomplished this feat while working for his master, and Job ben Solomon completed it three times during his stay in England (Diouf 1998, p. 117). 
of the documents he was able to analyze were completely consistent with those from the Maghreb and West Africa, including the practices they recommended from al-Suyūtî's Kitäb ar-Rahmah (Reichert 1967, p. 100). Verses of al-Busịirís Burda were found in fragments analyzed by Monteil as well (Monteil 1967, p. 90), a book from Rio Grande do Sul also contains two incomplete copies of the Burda (Dobronravin 2009, p. 166), and Étienne recorded that alufá in Brazil preferred the commentator "Bunu Selami" (Brazil 1909, p. 83; Étienne 1909, p. 102). It is not clear who this figure might be, but it could be Ibn Salim, another epithet for Shaykh Ahmad Tijānī as the name does not correspond to authors of the most popular tafsīr in the West African "core curriculum" at the time such as Tafsìr al-Jalālayn or even Abdallahi dan Fodio's Diyā al-ta'wīl fì ma'ānī 'l-tanzīl (Hall and Stewart 2011). It could have been a work attributed to Shaykh Ahmad Tijānī that was not a "commentary" at all like the very popular Jawāhir al-Ma'annī, or it could have been a reference to a tafsīr that was brought in from a route other than West Africa, although this is less likely. In any case, with such a large number of learned scholars-particularly in the early to mid-nineteenth century-they could likely have reproduced some works entirely from memory, and this was done in other areas with smaller texts, the Qur'an as noted above, and even Ibn Abī Zayd's Risālah in Georgia (Diouf 1998, 125-28). Although it is difficult to ascertain what works alufá in Brazil would have been familiar with, studied, and upon which they were tested, there is every reason to believe that the earliest leaders would have been familiar with the West African "core curriculum," had ample time and resources (relatively speaking) to recreate and teach them, and they were undoubtedly able to reestablish their traditions of Islamic erudition to at least a certain extent in Brazil.

\section{Muslim Black Atlantic}

The establishment and continuation of Islamic traditions of erudition in Brazil was dependent upon Brazilian Muslim communities integrating themselves into the broader Black Atlantic World and employing the waterways of the Atlantic to facilitate the mass movement of goods, ideas, and people. Rather than being cut off from their homelands, they were often in remarkably close contact. Those who bought or were given their freedom often were able to save enough money to move back to West Africa in thousands, but many also subsequently returned to Brazil after the abolition of slavery. Sometimes only part of these families would return to Brazil, leaving some members in major port cities like Lagos or Ouidah. These families would keep in touch, and it was not uncommon for children to be sent to West Africa to be educated and grow up familiar with African culture and languages before being brought back to Brazil. In short, those with enough means often had their family lives structured around the Atlantic Ocean, anchored by port cities in Brazil and West Africa (Law 2004; Turner 1942, p. 59; Castillo 2016). Peel and Matory have argued that diaspora, cosmopolitanism, and transnationalism based around the Atlantic were integral parts of the creation of both a Yoruba imagined community as well as Christian and orișa (traditional Yoruba deities)-worshipping communities in what is now Yorubaland and beyond (Peel 2000; Matory 2005; Matory 1999). With the experiences and history of Afro-Brazilian Muslim returnees, particularly those who founded the initial Muslim communities in important port cities, the same argument can and should be made with respect to Islam and many coastal West African Muslim communities as well. In fact, if the establishment of Christianity in Yorubaland was tied to a narrative of prosperity as an avenue for engaging with modernity as Peel has pointed out, one could argue that Muslim repatriates and members of the Muslim Black Atlantic offered a similar narrative and membership in a transnational community whose identity was also enmeshed with diaspora and prosperity through its knowledge of the modern world.

This dynamic movement was facilitated by lucrative shipping lines that operated almost continuously between Bahia and Lagos primarily but also Rio de Janeiro and Recife and Lagos up until World War I (Turner 1942, pp. 59-60; da Costa e Silva 2001, p. 88). This provided the opportunity to make significant profits through the trade in West African goods, which were quite common in places like Salvador and Rio well into the twentieth 
century and allowed Muslim communities to stay connected to West African homelands. Nile Green has shed light on how Bombay emerged as a major center in a broader Indian Ocean Muslim community through its prominent place within the economics of the region and new ways in which Islam became interwoven with it (Green 2013). Although Brazilian cities may not have emerged as major production centers for Islamic goods and ideas that were subsequently exported to other parts of the Muslim Black Atlantic, a similar case could be made for Brazil. Salvador in particular emerged as an urban center that was intimately connected to other important urban centers along the Atlantic coast in Africa and Brazil through a combination of religious and economic ties, and certainly operated as a focal point for these exchanges and movements of goods and people.

However, it was the end of these shipping lines that left Muslims in Brazil isolated to a greater degree than before, and da Costa e Silva credits this with the beginning of full assimilation with non-Muslims as their previous contacts were what sustained the community as a minority within a minority population (da Costa e Silva 2001, pp. 88-89). This is significant because if the decline were indeed due to simple assimilation, it likely would have taken place much earlier or at least to a greater degree. The fact that the Muslim community's eventual disappearance became inevitable only after the closing of these trade routes indicates that while the community may have lacked the strength to support itself independently, it was at least strong enough to maintain a distinctive identity with the support of West African connections. African Muslim women were brought to the Americas and Brazil in very small numbers (Lovejoy 2016, pp. 150,174, 198), and the short supply of potential Muslim wives certainly also was a significant factor. However, it is clear that Muslim men married non-Muslim women and raised Muslim families, the perpetual contact with family and Muslim communities in West Africa could address this issue to a degree, and young scholars born in Brazil were still being confirmed in the twentieth century, indicating that the Afro-Brazilian Muslim community was, for a time, able to reproduce itself. ${ }^{27}$ Their children did often embrace other religions, decreasing their numbers further, and ensuring that it could not survive the severing of links with West Africa (Rodrigues 2010, pp. 67-68; da Costa e Silva 2001, pp. 88-89).

While it is not entirely clear why the shipping lines closed and were not reopened, several factors likely contributed to this state of affairs. First, travel and trade had begun to decline at the end of the nineteenth century and the exportation of palm products stagnated, with no more than two ships traveling between Bahia and Lagos each year (Castillo 2016, p. 41). Second, the European demand for West African products like palm oil, palm kernels, and groundnuts rose dramatically just before and after the war to fuel European industries (Hopkins 2020, pp. 177-80). Third, a great number of European trading firms were established in Lagos at the beginning of the twentieth century that weakened the position of African merchants, and the expansion of colonial control made Lagos more firmly integrated into the European economy as a "dumping ground for European markets" (Olaoba and Ojo 2014, pp. 122-23, 130). Fourth, Britain exercised tight control of Lagos's imports and exports, which caused a severe depression in the early 1920s after the British manipulated the European markets for African goods, and this depression practically ground commerce to a halt and affected African merchants most intensely (Olukoju 1992). Together, these factors redirected most commerce in the area toward Europe and its industries and marginalized the African merchant class which included those Brazilian returnees who would be more inclined to trade with Brazil again. Consequently, the shipping lines were never reopened (Hopkins 2020, pp. 80-81).

During this period from the early nineteenth to the early twentieth century, these returnees were not only involved in trade but also further study in West Africa-including at times modern, Western education. Bastide reports that "free members of the [Muslim]

27 For example, Dobronravin has analyzed an Ajami letter written by a Muslim about how his wife gave birth to a daughter and Baghdādī wrote a short section about the state of women, wives, and marriage in the Muslim community, mostly registering his disapproval of their practices (Dobronravin 2009, pp. 162-64; al-Baghdādī 2001, pp. 16-17, 28-29). Reis also describes how women were integrated into the Muslim community, as well (Lovejoy 1994, pp. 107-8). 
community even went to Africa to study so that they might later devote themselves to teaching the slave population in Brazil" (Bastide 1978, p. 147). Although it is unclear where he got the information, Goody reports that the Imam Abubakar, who was supposedly the leader of the Muslim community and the rebellion in Salvador in 1835, traveled back to Nigeria and then returned to Brazil "as a result of his faith" (Goody 1986, p. 329). Paulo José Ferreira was born in Bahia to Yoruba parents in 1886, but returned to Nigeria in 1889 with his family where he grew up as a Muslim. Eventually he returned to Brazil but maintained close connections with family in both Lagos and Kano with whom he was still in touch in the 1930s and 40s. Fluent in Yoruba, Arabic, and Portuguese, he worked in Rio de Janeiro selling African items and offering his religious services to both white and black Brazilians and was able to make enough money to "give considerable aid to his children in Africa" (Turner 1942, pp. 64-65). From a Yoruba perspective, the only strange part of Ferreira's story is that he spoke Portuguese and worked in Brazil as it was quite common for Yoruba men who wished to become alfa (the Yoruba word for a Muslim scholar or cleric) to study in major centers like Ilọin or Kano, establish family connections there, and return to their communities to teach. Ferreira's network had just been expanded from Yorubaland to include his communities in Brazil. Not all remained Muslims in the Americas like the famous Mahommah Gardo Baquaqua, born into a Borgu scholarly family in Djougou in present-day Bénin. He received some Islamic education in Djougou, was captured and taken to Brazil for two years, obtained his freedom with the help of abolitionists when serving as a cabin boy on a ship that traveled to the United States, and ultimately studied at New York Central College. ${ }^{28}$ Of course, Muslim scholars were just one part of this larger class of trans-Atlantic travelers and merchants which included Muslims and non-Muslims, but their presence and activity as religious experts has not received the same attention as those who practiced Afro-diasporic religions. ${ }^{29}$

Perhaps the best example of a scholar who operated within the Muslim Black Atlantic was a man known as Rufino in Brazil but "Abuncare" (perhaps Abubakari/Abu Bakr?) in Africa. ${ }^{30} \mathrm{He}$ is notable mostly because we just happen to know his life story as a result of his arrest and trial for allegedly forming a seditious sect in Recife in 1853. João José Reis, Flávio dos Santos Gomes, and Marcus J. M. de Carvalho have written a fascinating account of his life and times in O Alufá Rufino: Tráfico, Escravidão e Liberdade no Atlântico Negro which reveals many important details. First, he was born in the old capital of Oyo at the beginning of the nineteenth century as a prince and son of a Yoruba alfa and teacher and began his studies there (Reis et al. 2010, pp. 13-16). He got caught up in the civil war that caused the decline of the Oyọ Empire, was captured by Hausa forces, sold into slavery, and arrived in Bahia in 1822-3, indicating that if he began his studies at a young age as is likely, then he could have advanced quite far before being taken captive (Reis et al. 2010, pp. 20-22).

Rufino was taken to many different places in Brazil, bought his freedom and then worked as a cook on a slave ship before being captured by the British and taken to Sierra Leone for a time in 1841. There he took advantage of the sizeable Yoruba and Fulani population of Fourah Bay (a quarter of Freetown) to further his studies for several months. Several mosques and schools (called ile kewu as they are in Yorubaland) had been set up there just before Rufino's arrival, and many of the religious leaders, such as Mohammed Yadalieu, were also successful traders in the Atlantic world (Reis et al. 2010, pp. 285-88, 381-82). Rufino returned to Brazil, but in 1845 he decided to travel to Fourah Bay yet again to complete his studies, this time staying for nineteen months. Although higher education in Islamic sciences was available in Freetown and nearby Futa Jallon, it is unlikely that

28 For more on the fascinating life of Baquaqua, including his autobiography, see Law and Lovejoy (2006).

29 See Castillo for good description of the travels of these entrepreneurs (Castillo 2016, pp. 31-34).

30 It seems most likely that his Muslim name was indeed Abu Bakr as a Jamaican Muslim of the same name was at times called "Abon Becr" which is quite close (Wilks 1967, pp. 152-69). 
Rufino was able to progress that far before he returned to Brazil the second time. ${ }^{31} \mathrm{He}$ moved first to Bahia, where he was welcomed as a leader to connect with a son he had left behind, and then both moved to Recife where he settled down (Reis et al. 2010, pp. 361-68).

Once in Recife, Rufino set up a successful practice, serving Africans and black and white Brazilians of all religious backgrounds, and it is interesting that he never returned to his previous profession as a cook, preferring to make his living on the basis of his Islamic education (Reis et al. 2010, pp. 367, 379). However, he did not only support himself on his income from divination and amulet making. A newspaper article that pushed strongly for his imprisonment stated that his devotees were "exploited" and "obliged" to provide for his needs (Reis et al. 2010, p. 378; da Costa e Silva 2001, p. 86), which is without doubt the common West African arrangement in which students work for and support their teachers in exchange for and as part of their education. ${ }^{32}$ His following caught the attention of the authorities in 1853, and because there was such widespread fear that he was going to lead an insurrection, he was arrested and his house/school searched. In his home they found wooden boards; rosaries; papers and book manuscripts in Arabic; pens; black, blue, and red ink; an expensive copy of the Qur'an he had brought from Sierra Leone; a manuscript of a new copy of the Qur'an he was in the process of transcribing; and several other books for "prayers ... teaching medicine, and others that taught his language [Arabic]" (Reis et al. 2010, p. 386). He was apparently also in the process of writing other manuscripts containing prayers, songs, and even sermons. One such sermon was prepared for a marriage ceremony, written in excellent Maghribi script, and demonstrated that while he had a high degree of learning and commanded respect from the Muslims of Recife, there was indeed nothing to suggest that he was organizing a rebellion (Reis et al. 2010, pp. 389-91). When asked why he did not use his abilities to make more money, Rufino responded, "Some ask God for riches, but I only asked for knowledge; the two cannot fit in one bag" (Reis et al. 2010, p. 395). Rufino's statement and life story echo those of Mohammad-Abdullah, and the extension of the Bilad al-Sudan into Brazil not only allowed him to pursue the knowledge he desired, but also to support himself by practicing it and teaching it to others.

While the West African-derived Muslim tradition in Brazil ultimately declined and ended sometime in the mid twentieth century, the importance of specifically West African Islamic traditions is still relevant today. Gomez posited that a Nigerian Muslim mission in Salvador operating in the 1990s might revive it (Gomez 2005, p. 127). Indeed, there are many signs that this is in fact happening. There is currently a mosque and Islamic center in Salvador that is run by a Yoruba shaykh named Abdul Hameed Abu Bakr Ahmad who has been leading the community since 1992 . He was brought to lead the community after two Lebanese and Yoruba businessmen met with Dr. Ade Bello, the representative of WAMY (World Assembly of Muslim Youth) in Lagos and agreed that a Nigerian shaykh would be the best fit for the community given its ethnic makeup and cultural history. Shaykh Ahmad completed studies at the Islamic University in Madinah before returning to Nigeria where he worked until 1992. He was initially hesitant to come to Brazil and agreed to come for only five years until the community was consolidated and ready for another leader. However, he quickly realized the wisdom of the choice of a Nigerian, and specifically Yoruba, leader and has remained the spiritual leader of the steadily growing community.

At first the Muslim community was composed primarily of African and Middle Eastern immigrants, with West Africans and Yoruba Nigerians featuring prominently. These West African and Yoruba immigrants were not descendants of the Malês, but rather mostly students and entrepreneurs who traveled to Brazil voluntarily in search of greater economic opportunity beginning in the 1980s. Thus, although linkages between West African

31 Although Reis cites Futa Toro, he likely intended Futa Jallon (Reis et al. 2010, p. 382).

32 Ware has highlighted how Western observers have reproduced this prejudicial discourse of exploitation from the time of colonialism in Senegal to the contemporary era with human rights groups, once again stressing the continuity of this unified Islamic tradition and Western reactions against it (Ware 2014, pp. 39-48). 
Muslims and this part of Brazil were severed for a time, this new wave of migration reestablished contact and allowed for the opportunity to build upon the previous history. As a result, Salvador's Muslim community has steadily gained more and more converts from Brazil, and it is precisely the ability to interact with Brazilians of all religious backgrounds and to connect a contemporary Muslim identity to both an African and Brazilian past that makes Shaykh Ahmad's background so important. Because of the history of the Malês, particularly the rebellion in 1835, many Brazilians are eager to hear from him as a Yoruba Muslim about Islam in Yoruba society and its place in Salvador's history. He has even spoken with descendants of those who took part in the rebellions and this important point of contact has generated a great deal of interest in the center amongst Brazilians of all religious backgrounds. Furthermore, he says that he relies heavily on his personal background in a multi-religious society and knowledge of traditional Yoruba religion to foster positive relations with both Christians and those who practice Candomble (dominated by the worship of Yoruba deities). According to him, "if they sent an Arab shaykh here, it can't work," because it would be difficult for them to understand how these traditions operate, and why some who are interested in Islam still have their lives tied to such traditions. In fact, when they held a conference in an auditorium at a Catholic institution, an invited scholar from the Persian Gulf was furious because there was a crucifix in the room and wanted the event moved because it was haram, reinforcing to Shaykh Ahmad that when he needs to find a replacement he would look for someone from Ghana, Benin, or Nigeria. As the leader of a minority religious group composed of many different ethnic backgrounds, the ability to understand other more popular religious traditions, articulate productive ways of engaging with them that are rooted in Islamic traditions, and teach about Islam in a way that is comprehensible to outsiders is of paramount importance. Combined with the general interest in Yoruba culture, and Malê history in particular, Shaykh Ahmad's background provides the community with all of these benefits quite naturally. ${ }^{33}$

A growing number of African migrants in major cities like São Paulo and Rio de Janeiro in recent decades has caused a rise in their Muslim populations as well, making events in Salvador not unique at all. In Rio, the largest Muslim organization, Sociedade Beneficente Muçulmana do Rio de Janeiro (SBMRJ), has recently been led by a Sudanese man who could leverage his identity as a black African to connect with the African constituency and black Brazilian population, as well as his Arab identity for that part of the community (da Rocha Pinto 2014, p. 244). This community also has to forge alliances with other minority religious groups - most notable among them Afro-diasporic religions like Candomblé and Umbanda-putting concepts of religious pluralism and interaction at a premium (da Rocha Pinto 2014, p. 245).

\section{Conclusions}

Malês or African Muslims formed a large percentage of Brazil's colonial population in major cities like Salvador, Rio de Janeiro, and Recife, although the study of their communities has been largely overshadowed by that of practitioners of Afro-diasporic religions and mostly linked to their strong history of rebellion. Consequently, when discussing the strong networks that were created around the Black Atlantic, using the ocean as a vector for communication and exchange, Muslims have largely not been factored into the equation. I have sought to demonstrate how African Muslims and their descendants in Brazil were uniquely positioned to be able to recreate West African traditions of Arabic literacy and education in their new land, and also were connected with the broader Black Atlantic world, effectively extending the bilad al-Sudan into coastal Brazil. Most of the Malês were ethnically Hausa, Kanuri, Fulani, Nupe, and Yoruba, were captured as a result of religio-political wars of the late eighteenth to early nineteenth centuries, and came from a deeply connected region of Islamic scholarship and practice. Many of those who came had already achieved a high degree of Islamic education before being taken to Brazil

33 Shaykh Abdul Hameed Abu Bakr Ahmad. Personal Interview, 18 January 2017. 
and became religious leaders and teachers of fairly large Muslim communities even in their captivity.

Because of Western stereotypes about Africans who came from these areas, they were most often made to work in large urban environments, at times under little supervision, and allowed to work in groups with others from their same homelands in Africa. These ethnic and regional support networks, based on models from back home, were frequently leveraged to help them take advantage of the legal option of Brazilian slaves to buy their own freedom. Arabic literacy and Islamic education often afforded such Malês the opportunity to gain extra income through amulet making and the marketing of their religious services, and the relatively large amount of free time they had allowed for a certain amount of study and teaching, as well. Many Muslim slaves and freedmen opted to live together and, in some cases, either built or rented buildings or rooms that could be used for religious practice and instruction.

Because more Africans lived and worked in Salvador than any other city in Brazil, it emerged as the center and seat of Islamic authority in Brazil, even after the killing and dispersal of many African Muslims following the rebellion in 1835. The imam in Bahia would set the calendar and exercised authority over the leaders in the other urban centers in much the same way that the Sultan of Sokoto is and was the paramount leader amongst the Hausa city states in Northern Nigeria. This community ultimately began to decline just after the turn of the century with the closing of shipping lines and trade routes connecting them to West Africa and had practically died out by the 1970s or 1980s at the very latest.

Just as Islam won converts in Yorubaland at the time, many mostly Yoruba slaves joined the ranks of the Malês in Brazil, and contemporary writers were all struck by the usually higher level of literacy amongst the Malês than their white masters. This literacy was certainly and widely employed in the creation of amulets, but perhaps too much emphasis has been placed on this activity because of the general focus both at the time and in subsequent scholarship on the role of Islamic scholars and leaders in armed rebellion. These leaders also managed to establish schools, teach others to read and write Arabic, and continued the tradition of Ajami as well. Some writing materials such as black ink and writing boards were recreated locally, and others such as prayer beads, red and blue ink, and paper were imported, often at high costs. Malês continued to write in the Maghribi script, and despite the high cost of paper, they wrote an incredible amount of material. Letters were exchanged between those within the same city, between cities in Brazil, and between those in Brazil and West Africa. A profitable trade in general items from the West African coast and Islamic goods took place, and the best-selling product of a French bookstore in Rio was the Qur'an for quite a while. The educational system established must have been fairly robust because it managed to produce new scholars and leaders into the twentieth century, as evidenced by the examinations and celebrations held at their completion in Rio. The scholars who led these communities studied and taught major texts common in West Africa at the time and may have either imported or transcribed some of them from memory too.

The examples of Rufino or Abuncare and Shaykh Ahmad demonstrate how the exportation of West African Islamic traditions has played a central part in the history of Islam in Brazil in historical and contemporary perspective. Rufino's life illustrates many of the features of what I have called the Muslim Black Atlantic. Primary among these are the importance of Islamic learning through the education he received in pre-colonial Yorubaland and in two periods of study in Sierra Leone and the way he was able to use it to serve and educate others in Brazil on the basis of his Islamic education. Shaykh Ahmad also received initial education in Yorubaland, went to Saudi Arabia for higher education, and was recruited to lead the Muslim community in Salvador specifically because of his background and the opportunities it offered to connect with Brazil's Afro-diasporic population. Although the link was even more direct and firm in the past, the unique history of Africans in Brazil caused its Islamic traditions to be inherently linked to and built upon those of the Bilad al-Sudan, giving rise to the Bilad al-Brazil. 
Funding: This research was funded by the American Academy of Religion's Selva J. Raj Endowed International Dissertation Research Fellowship.

Data Availability Statement: Not applicable.

Acknowledgments: I would like to thank Doté Amilton Costa for hosting me during my research in Salvador, Shaykh Abdul Hameed Abu Bakr Ahmad for his time and generosity, Ousmane Kane and Zekeria Salem for their advice and guidance for my research and including it in this special edition, and the reviewers of the article for their helpful suggestions and thorough review.

Conflicts of Interest: The author declares no conflict of interest.

\section{References}

Ajayi, Jacob. 1961. Nineteenth Century Origins of Nigerian Nationalism. Journal of the Historical Society of Nigeria 2: 196-210.

al-Baghdādī, 'Abd al-Raḥmān. 2001. The Amusement of the Foreigner, trans. Yacine Daddi Addoun and Renée Soulodre-La France. Toronto: York University, pp. 7-8.

Austen, Ralph A. 2010. Trans-Saharan Africa in World History. Oxford: Oxford University Press.

Awoniyi, Timothy. 1981. The Word Yoruba. Nigeria 134: 104-7.

Bastide, Roger. 1978. The African Religions of Brazil: Towards a Sociology of the Interpenetration of Civilizations. Translated by Helen Serba. Baltimore: Johns Hopkins University Press.

Blair, Sheila S. 2008. Arabic Calligraphy in West Africa. In The Meanings of Timbuktu. Edited by Shamil Jeppie and Souleymane Bachir Diagne. Cape Town: HSRC Press.

Brazil, Étienne Ignace. 1909. Os Malês. Revista do Instituto Historico e Geographico Brazileiro 72: 86.

Capone, Stefania. 2011. Le Pai-De-Santo Et Le Babalawo. In La Religion Des Orisha: Un Champ Social Transnational En Pleine Recomposition. Edited by K. Argyriadis and Stefania Capone. Paris: Hermann Editions.

Castelnau, Francis. 1951. Renseignments sur l'Afrique central et sur une nation d'hommes a queue qui s'y trouvait, d'après les rapports des Nègres du Soudan, esclaves à Bahia.. Paris: P. Bertrand.

Castillo, Lisa. 2016. Mapping the Nineteenth-Century Brazilian Returnee Movement: Demographics, Life Stories, and the Question of Slavery. Atlantic Studies 13: 30. [CrossRef]

Curtis, Edward, IV. 2014. The Call of Bilal: Islam in the African Diaspora. Chapel Hill: University of North Carolina Press.

da Costa e Silva, Alberto. 2001. Buying Korans in Nineteenth-Century Rio de Janeiro. Slavery E Abolition 22: 87.

da Rocha Pinto, Paulo Gabriel Hilu. 2014. Muslim Identities in Brazil: Engaging Local and Transnational Spheres. In The Middle East and Brazil. Edited by Paul Amar. Bloomington: University of Indiana Press.

de Drumond, Menèzes. 1826. Lettres sur 1'Afrique ancienne et modern, adressées au Rédacteur du Journal des voyages. Journal des voyages 32: 205.

Diouf, Sylviane. 1998. Servants of Allah: African Muslims Enslaved in the Americas. New York: New York University Press.

do Rio, João. 1906. Religiões no Rio. Paris: H. Garnier.

Dobronravin, Nikolay. 2009. Literacy among Muslims in Nineteenth-Century Trinidad and Brazil. In Slavery, Islam, and Diaspora. Edited by Behnaz A. Mirazi, Ismael Musah Montana and Paul E. Lovejoy. Trenton: Africa World Press.

Dobronravin, Nikolay. 2014. West African Ajami in the New World (Hausa, Fulfulde, Mande Languages). In The Arabic Script in Africa. Edited by Meikal Mumin and Kees Versteegh. Leiden: Brill.

Étienne, Ignace. 1909. La Secte musulmane des Malès du Brésil et leur révolte en 1835. Anthropos 4: 103.

Ewbank, Thomas. 1856. Life in Brazil: Or, A Journal of the Visit to the Land of the Cocoa and the Palm. With an Appendix, Containing Illustrations of Ancient South American Arts. New York: Harper \& Brothers.

Freyre, Gilberto. 1986. The Masters and the Slaves: A Study in the Development of Brazilian Civilization [Casa-grande E senzala]. Translated by Samuel Putnam. Berkeley: University of California Press.

Gardner, George. 1849. Travels in the Interior of Brazil: Principally through the Northern Provinces and the Gold and Diamond Districts during the Years 1836-1841. London: Reeve, Benham, and Reeve.

Gilroy, Paul. 1993. The Black Atlantic: Modernity and Double Consciousness. Cambridge: Harvard University Pres.

Gomez, Michael. 1990. Timbuktu under Imperial Songhay: A Reconsideration of Autonomy. Journal of African History 31: 4-24. [CrossRef]

Gomez, Michael. 2005. Black Crescent: The Experience and Legacy of African Muslims in the Americas. New York: Cambridge University Press.

Goody, Jack. 1986. Writing, Religion and Revolt in Bahia. Visible Language 30: 328.

Green, Nile. 2013. Bombay Islam: The Religious Economy of the Western Indian Ocean, 1840-1915. Cambridge: Cambridge University Press.

Hall, Bruce S., and Charles C. Stewart. 2011. The Historic 'Core Curriculum' and the Book Market in Islamic West Africa. In The Trans-Saharan Book Trade: Manuscript Culture, Arabic Literacy and Intellectual History in Muslim Africa. Edited by Graziano Krätli and Ghislaine Lydon. Leiden: Brill.

Hopkins, Anthony Gerald. 2020. An Economic History of West Africa, 2nd ed. New York: Routledge. 
Hunwick, John. 1996. Secular Power and Religious Authority in Muslim Society: The Case of Songhay. Journal of African History 37: 175-94. [CrossRef]

Isfahani-Hammond, Alexandra. 2014. Slave Barracks Aristocrats: Islam and the Orient in the Work of Gilberto Freyre. In The Middle East and Brazil. Edited by Paul Amar. Bloomington: Indiana University Press.

Kane, Ousmane Oumar. 2016. Beyond Timbuktu: An Intellectual History of Muslim West Africa. Cambridge: Harvard University Press.

Karasch, Mary. 1987. Slave Life in Rio De Janeiro, 1808-1850. Princeton: Princeton University Press, p. 26.

Kent, Raymond K. 1970. African Revolt in Bahia: 24-25 January 1835. Journal of Social History 3: 342. [CrossRef]

Law, Robin. 1997. Ethnicity and The Slave Trade: 'Lucumi' and 'Nago' as Ethnonyms in West Africa. History in Africa 24: 205-19. [CrossRef]

Law, Robin. 2004. Yoruba Liberated Slaves Who Returned to West Africa. In The Yoruba Diaspora in the Atlantic World. Edited by Toyin Falola and Matt Childs. Bloomington: Indiana University Press.

Law, Robin, and Paul Lovejoy. 2006. The Biography of Mahommah Gardo Baquaqua: His Passage from Slavery to Freedom in Africa and America. Princeton: Markus Wiener Publishers.

Lindsay, Lisa A. 1994. 'To Return to the Bosom of their Fatherland': Brazilian Immigrants in Nineteenth-Century Lagos. Slavery $\mathcal{E}$ Abolition 15: 22-50.

Lovejoy, Paul. 1993. Murgu: The Wages of Slavery in the Sokoto Caliphate. Slavery and Abolition 14: 168-85. [CrossRef]

Lovejoy, Paul E. 1994. Background to Rebellion: The Origins of Muslim Slaves in Bahia. Slavery \& Abolition 15: $156-57$.

Lovejoy, Paul. 2016. Jihad in West Africa During the Age of Revolutions. Athens: Ohio University Press.

Lydon, Ghislaine. 2009. On Trans-Saharan Trails Islamic Law, Trade Networks, and Cross-Cultural Exchange in Nineteenth-Century Western Africa. Cambridge: Cambridge University Press.

Mann, Kristin, and Edna Bay. 2001. Rethinking the African Diaspora: The Making of a Black Atlantic World in the Bight of Benin and Brazil. London: Frank Cass.

Matory, J. Lorand. 1999. The English Professors of Brazil: On the Diasporic Roots of the Yoruba Nation. Comparative Studies in Society and History 41: 72-103. [CrossRef]

Matory, J. Lorand. 2000. Surpassing 'Survival': On the Urbanity of 'Traditional Religion' in the Afro-Atlantic World. The Black Scholar 30: 36-43. [CrossRef]

Matory, J. Lorand. 2005. Black Atlantic Religion: Tradition, Transnationalism, and Matriarchy in the Afro-Brazilian Candomblé. Princeton: Princeton University Press.

Mintz, Sidney Wilfred, and Richard Price. 1992. The Birth of African-American Culture an Anthropological Perspective. Boston: Beacon Press.

Monteil, Vincent. 1967. Analyse des 25 documents arabes des Malês de Bahia (1835). Bulletin de l'IFAN 29: 88.

Monteiro, Antônio. 1987. Notas sobres negros males na Bahia. Salvador: Ianamá.

Olaoba, Olufemi, and Oluranti Ojo. 2014. Influence of British Economic Activities on Lagos Traditional Markets, 1900-60. Journal of the Historical Society of Nigeria 23: 122-30.

Olukoju, Ayedele. 1992. Maritime Trade in the Aftermath of the First World War. African Economic History 20: 124-31. [CrossRef]

Palmié, Stephan. 2013. The Cooking of History: How Not to Study Afro-Cuban Religion. Chicago: University of Chicago Press.

Peel, John. 2000. Religious Encounter and the Making of the Yoruba. Bloomington: Indiana University Press.

Raeders, George. 1934. Le comte de Gobineau au Brésil. Paris: Les Nouvelles Editions Latines.

Reichert, Rolf. 1967. L'insurrection d'esclaves de 1835 à la lumière des documents arabes des Archives publiques de l'État de Bahia (Brésil). Bulletin de l'IFAN 29: 99-104.

Reis, João José. 1997. Slave Rebellion in Brazil: The Muslim Uprising of 1835 in Bahia. Blatimore: Johns Hopkins University Press.

Reis, João José. 2019. Ganhadores: A greve negra de 1857 na Bahia. São Paulo: Campanhia das Letras.

Reis, João José, and Beatriz Gallotti Mamigonian. 2004. Nagô and Mina: The Yoruba Diaspora in Brazil. In The Yoruba Diaspora in the Atlantic World. Edited by Toyin Falola and Matt Childs. Bloomington: Indiana University Press, pp. 77-110.

Reis, João José, Flávio dos Santos Gomes, and Marcus J. M. de Carvalho. 2010. O Alufá Rufino: Tráfico, Escravidão e LIberdade no Atlântico Negro (c. 1822-c.1853). São Paulo: Companhia das Letras.

Reis, João José, Flávio dos Santos Gomes, and Marcus J. M. de Carvalho. 2020. The Story of Rufino: Slavery, Freedom, and Islam in the Black Atlantic, trans. Sabrina Gledhill. New York: Oxford University Press.

Ricard, Robert. 1948. l'Islam noir à Bahia:d'après les travaux de l'école ethnologique brésilienne. Hespéris 35: 64.

Rodrigues, Raymundo Nina. 2010. Os Africanos no Brasil. Rio de Janeiro: Centro Edelstein de Pesquisas Sociais.

Scheele, Judith. 2010. Traders, Saints, And Irrigation: Reflections On Saharan Connectivity. The Journal of African History 51: 281-300. [CrossRef]

Turner, Lorenzo D. 1942. Some Contacts of Brazilian Ex-Slaves with Nigeria, West Africa. Journal of Negro History 27: 55-67. [CrossRef]

Ware, Rudolph T. 2014. The Walking Qur'an: Islamic Education, Embodied Knowledge, and History in West Africa. Chapel Hill: University of North Carolina Press.

Wilks, Ivor. 1967. Abu Bakr al-Siddiq of Timbuktu" in Africa Remembered: Narratives of West Africans from the Era of the Slave Trade. Edited by Phillip Curtin. Madison: University of Wisconsin Press. 